UDC 541.1

\title{
STUDY OF THE SURFACE PROPERTIES OF MINERALS IN THE COMPOSITION OF TAILS OF DASHKESAN IRON ORES
}

\author{
A.A.Gulieva \\ M.Nagiyev Institute of Catalysis and Inorganic Chemistry, NAS of Azerbaijan \\ aybeniz.quliyeva.72@mail.ru
}

Received 04.08.2019

\begin{abstract}
Physico-chemical analysis methods investigated the oxidation and changes in the surface properties of minerals that are part of the tailings obtained from the iron ores of the Dashkesan mining and smelting combine. The results of laboratory studies that simulate heap leaching of non-ferrous metals from these wastes are presented. It is shown that sulfuric acid processing of tailings obtained from iron ores improves the properties of percolation materials and increases the percentage yield of non-ferrous metals in solution.
\end{abstract}

Keywords: tailings, heap leaching, sulphatization, metal recovery.

doi

\section{Introduction}

In recent years, heap leaching technology has become increasingly important in the mining industry, as it offers the opportunity to process poor ores and their waste. Heap leaching at the present time, is a very common practice; it is conducted at a mine with low capital intensity, which allows satisfactory management of production residues $[1,2]$. Heap leaching of ores and dumps accounts for about $20 \%$ of the annual world copper production [3]. The Metallurgy Laboratory of the National Technical University of Athens has developed and patented a new complex hydrometallurgical method suitable for the efficient and economical processing of ores with a low nickel oxide content [4]. The method includes heap leaching of ore with dilute sulfuric acid at ambient temperature, cleaning the solution from leaching, and extracting nickel and cobalt by electrolysis.
For the first time in the world, the authors of [4] have carried out investigation for the purpose of studing applicability of the heap leaching method for low grade laterites. Foreign hydrometallurgical practice indicates a high prospectivity of the use of heap leaching, primarily gold, copper and uranium from low-grade ores and waste from mining and mineral processing [5]. In [6], the patterns of percolation leaching of nickel from oxidized nickel ores from the Ural deposit are studied. The possibility of their processing by heap and underground leaching using sulfuric acid solutions with concentration $50-100 \mathrm{~kg} / \mathrm{m}^{3}$, and achievement of nickel extraction up to $80 \%$, is shown.

In recent years, in Azerbaijan on the territory of the Dashkesan mining and processing plant, there are observed huge accumulations of technogenic wastes that pollute the environment.
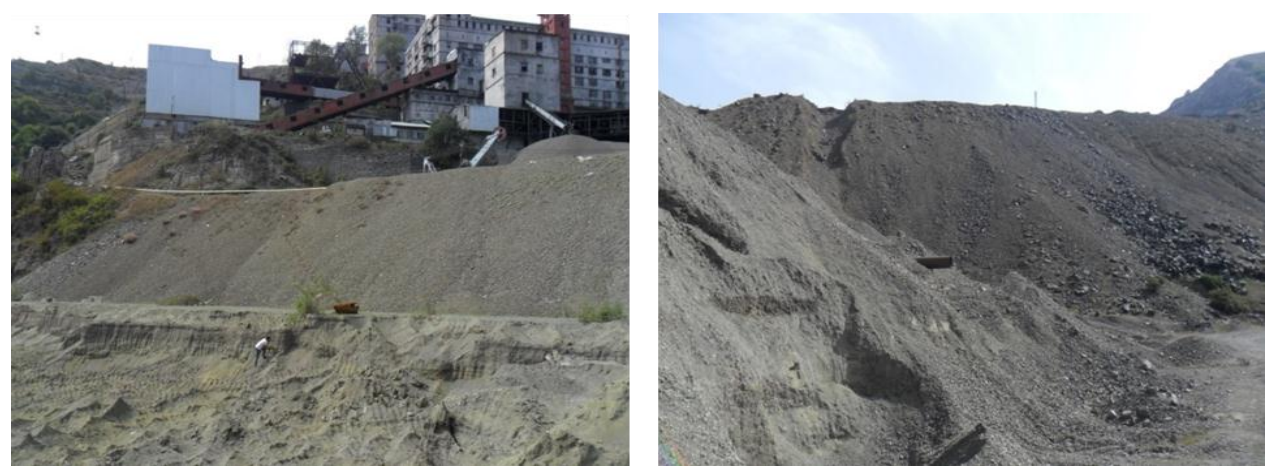

Fig. 1. Dump tails of Dashkesan mining and processing plant. 
Pollution is associated with the oxidation of unstable minerals in hypergene conditions, primarily iron sulphides and non-ferrous metals. Activation of the surface of minerals, occurring during the extraction process, their crushing and grinding, as well as chemical interaction of reagents, significantly intensifies the oxidation process, while technogenic waste is also a potential feedstock for the extraction of some valuable metals, such as $\mathrm{Co}, \mathrm{Cu}, \mathrm{Zn}, \mathrm{Mn}$ and $\mathrm{Al}$. Over the years, the plant has been accumulated more than 20 million tons of waste-tailings of wet magnetic separation. For the processing of such natural and technogenic raw materials, heap leaching of non-ferrous metals is promising.

In this work, physico-chemical analysis methods (XRD, IR spectroscopy, EDS analysis) investigated the oxidation and alteration of the surface properties of minerals that are part of the tailings of iron ores enriched in sulfuric acid leaching. Also the task was to study the possibility of heap leaching of $\mathrm{Co}, \mathrm{Cu}, \mathrm{Zn}, \mathrm{Mn}$ and $\mathrm{Al}$ in the laboratory.

\section{Experimental technique}

Under laboratory conditions the percolation test simulating heap leaching was carried out in experimental columns, the solution was fed from top to bottom (infiltration mode).

As the object of research, used dump tailings of the Dashkesan mining and processing plant, stored in the valley of the Goshgarchay river, were used. According to the results of X-ray phase analysis, it was found that the composition of the sample consists mainly of rock-forming minerals such as quartz, kaolinite, clinochlore, calcite, dolomite, pyrite, hematite and andradite. The content of sulfide minerals reaches $2.5 \%$. In appearance, enrichment tails are gray sand, the main fraction occurs in the range of $0.315 \pm 0.1 \mathrm{~mm}$. The enrichment tails sample contains non-ferrous metals, g/t: Co 27-60, Cu 432-517, Zn 155-204, $\mathrm{Pb} 82-120, \mathrm{Zr}-28$. The main components of the tails $(\%)$ are aluminum -2.7 , calcium -6.5 , iron 8.23 and silicon 15.9.

Percolation leaching was performed with $1 \mathrm{~N}$ sulfuric acid in columns with a diameter of $45 \mathrm{~mm}$ for 10 days. Pre-held moisture saturation of the current tails by water, the mass of loading tails was $500 \mathrm{~g}$. The pause between irrigations was 2-3 days, the volume of supplied acid $-100 \mathrm{ml}$. Solutions at the outlet from columns were analyzed by atomic absorption spectrometry, and the solid phase by XRD, IR spectroscopy and microscopic analysis.

\section{Experimental part}

For tailings of enrichment of iron ores, in order to improve percolation properties and increase the extraction of $\mathrm{Co}, \mathrm{Cu}, \mathrm{Zn}, \mathrm{Mn}$ and $\mathrm{Al}$ at heap leaching, we used sulfuric acid agglomeration $10 \%$ acid, with ratios $S: L=3: 1$, followed by leaching sulphated product by water. In Figure 2 shows the diffractograms of the tailings of the enrichment of iron ores $(a)$, as well as sulphated granules by a $10 \%$ solution of $\mathrm{H}_{2} \mathrm{SO}_{4}(b)$ and the cake after leaching the sulphated product by water $(c)$.

As can be seen from the diffractograms, andradite $\left(\mathrm{Ca}_{3} \mathrm{Fe}_{2}\left(\mathrm{SiO}_{4}\right)_{3}-40.3 \%\right.$, clinochlore $\left(\mathrm{Mg}, \mathrm{Fe}^{2+}\right)_{5} \mathrm{Al}_{2} \mathrm{Si}_{3} \mathrm{O}_{10}(\mathrm{OH})_{8}-9.3 \%$, manganese calcite $(\mathrm{Ca}, \mathrm{Mn}) \mathrm{CO}_{3}-14.8$, quartz $\left(\mathrm{SiO}_{2}\right)_{-}$ $13.3 \%$, hematite $\left(\mathrm{Fe}_{2} \mathrm{O}_{3}\right)-5.6 \%$, pyrite $\left(\mathrm{FeS}_{2}\right)-$ $8 \%$, dolomite $(\mathrm{Mg}, \mathrm{Ca}) \mathrm{CO}_{3}-3.0 \%$ it is present in insignificant quantities, as well as arsenopyrite was diagnosed. The diffractograms of the newly formed crust and current tails in the sample volume after the completion of the experiments on sulphatization with sulfuric acid and the initial fraction are almost identical. In addition, in Figure 2 (b), new sulphate gypsum phases $\left(\mathrm{CaSO}_{4} \cdot 2 \mathrm{H}_{2} \mathrm{O}\right)$, colorless epsomite $\left(\mathrm{MgSO}_{4} \cdot \mathrm{H}_{2} \mathrm{O}\right)$, in which the magnesium may be partially isomorphically substituted by iron, cobalt, herewith isappears intensity arsenopyrite and calcite, andradite intensity decreases. All this indicates the interaction with the sulphate solution of not only sulfide minerals, but also silicates. At the same time, chemically inert quartz and kuanite, during the experiments, practically did not dissolve.

Microphotographs of the dumps (before and after treatment with sulfuric acid solutions) show that under the influence of $\mathrm{H}^{+}$and $\mathrm{SO}_{4}{ }^{2-}$ ions, structural changes occur in the raw material, in particular, the destruction of phases, the appearance of voids, an increase in amorphism (Figure 3). 


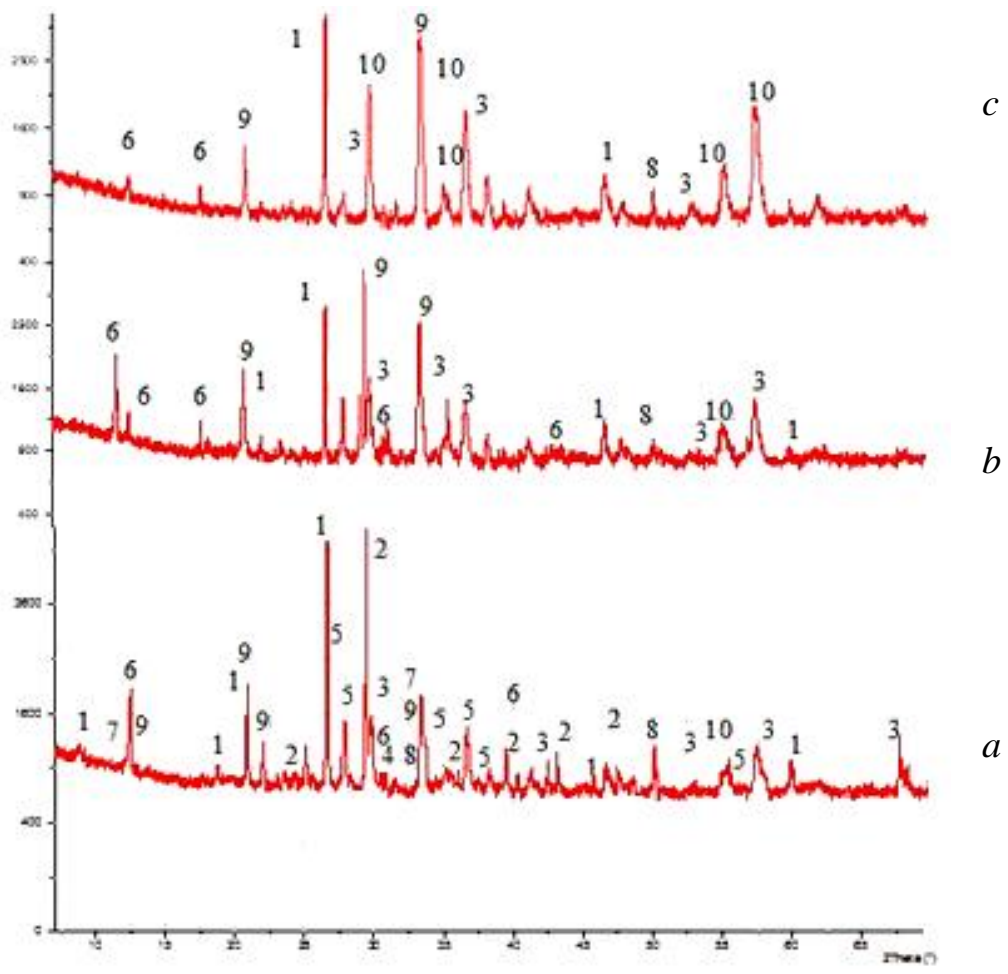

Fig. 2. Fragments of the diffractograms of tailings of enrichment of iron ore $(a)$, sulphated granules $(b)$ and cake after leaching of sulphated granules by water $(c)$ : $1-$ quartz, 2 - calcite, 3 - andradite, 4 - dolomite, 5 - arsenopyrite, 6 clinochlore, 7 - hematite, 8 quanite, 9 - gypsum, 10 - epidote.

$a$

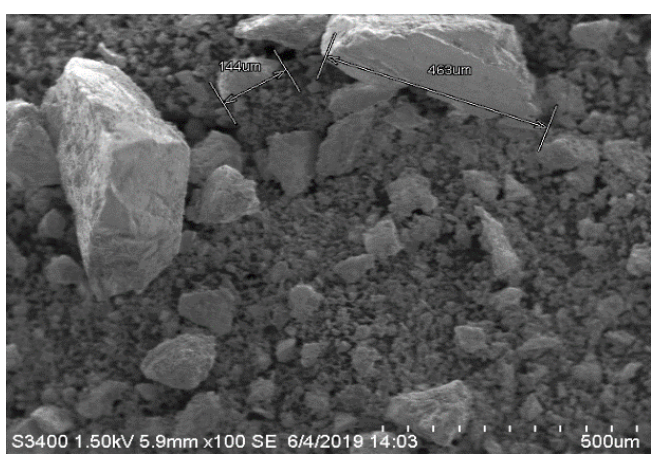

$b$

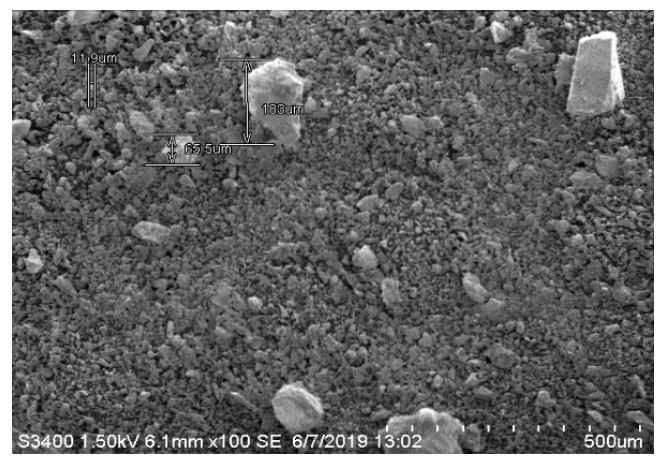

Fig. 3. Microphotographs of iron ore dumps before $(a)$ and after $(b)$ chemical processing $(\times 100)$. Dynamics of leaching of metals in the experiment is shown in Figure 4.
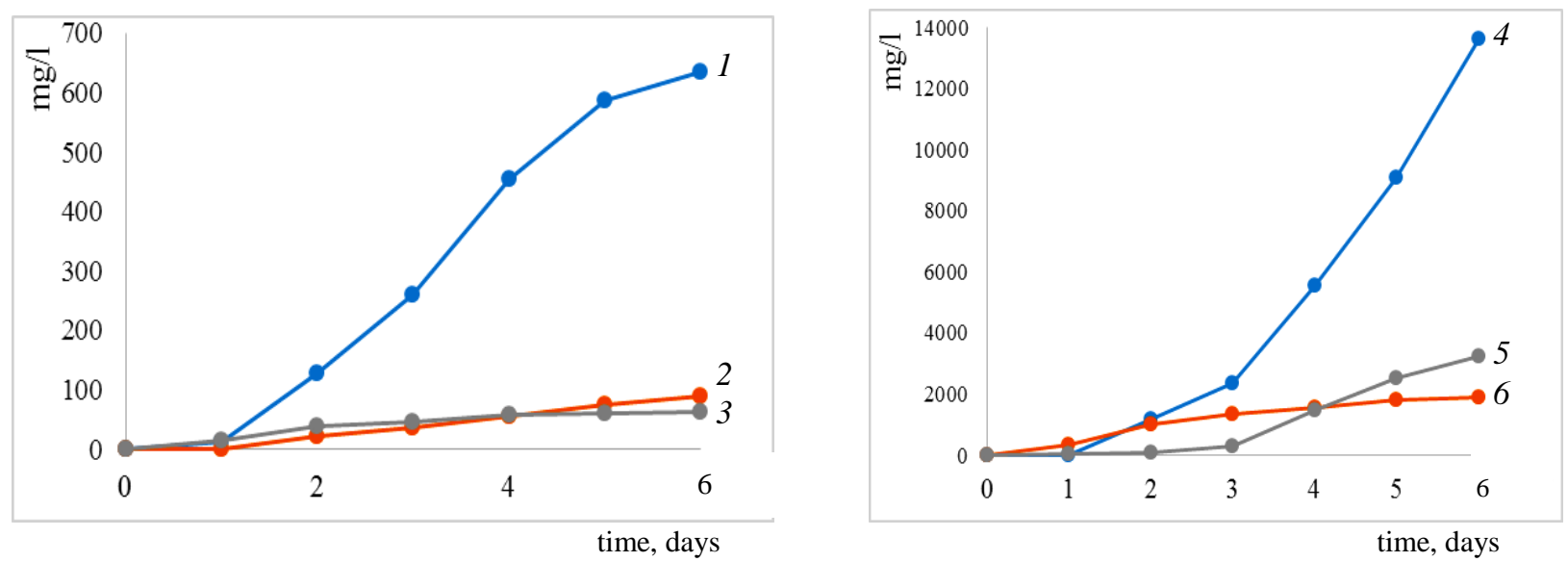

Fig. 4. The concentration of metals in productive solutions during leaching of tailings from enriched iron ores: $1-\mathrm{Cu}, 2-\mathrm{Zn}, 3-\mathrm{Co}, 4-\mathrm{Fe}, 5-\mathrm{Mn}, 6-\mathrm{Al}$. 
As can be seen from Figure 4, the leaching process of tailings proceeds quite intensively. The cobalt concentration in the solution is stable and is in the range of $15.6-58.9 \mathrm{mg} / \mathrm{l}$, although noteworthy are relatively high concentrations of copper, manganese and aluminum.

The sulphated samples of dumps were investigated using energy dispersive spectroscopy (EDS analysis) (sample № 1).

On the Figure 5 presented the results of the EDS-analysis of sample № 1 "from the site" at a hundredfold increase, which allow us to estimate the concentration of elements on the surface of tail particles.

According to the analysis, in sample 1 there are small particles of micron scale, against the background of which grains of irregular shape are visible, which are oxidized compounds of cobalt, manganese, iron, silicon, magnesium, aluminum, sulfur and calcium. Microanalysis data showed that in sulphated dumps a large amount of impurities of calcium (19.56\%), silicon $(21.84 \%)$, iron $(17.11 \%)$ are contained, while the concentration of magnesium, cobalt, nickel, potassium is less than $3 \%$ (0.9-2.78\%).

Based on the results of diffraction patterns, it can be concluded that the cake after leaching is presented mainly by such minerals as gypsum, quartz, epidote (Figure 2, c)

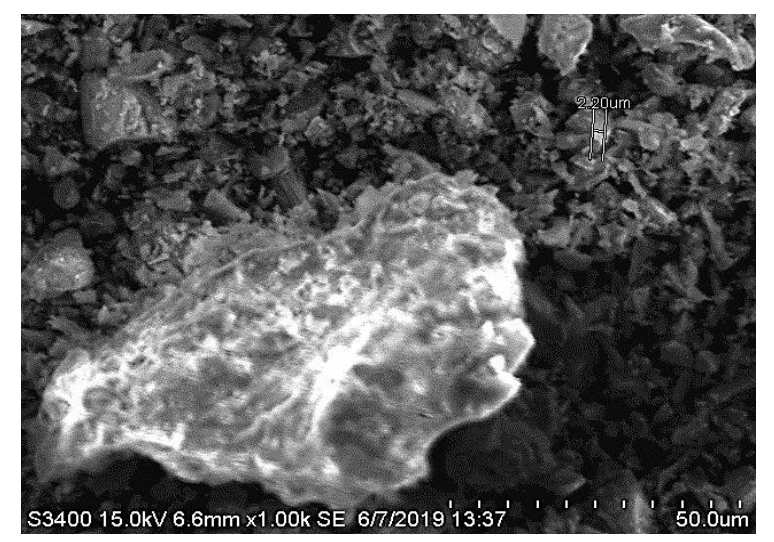

In the Figure 6 presented the IR spectra of the initial sample tail of enrichment, the neogenic phase after drying of sulfuric acid and after treatment by distilled water.

In general, it can be noted that, qualitatively, the spectra obtained are similar, that testified to proceeding the oxidation of the fine fraction of tailings during its storage in the dump. The difference between the samples is manifested in an increase in the intensity of the absorption bands corresponding to the valent and deformation fluctuations in the $\mathrm{OH}^{-}$of hydration water of the sulphates as well oxyhydroxides.

In the IR spectra of waste (Figure 6, b), folloving sulphatization by sulfuric acid, narrow absorption bands are observed in the region of stretching vibrations of $3000-3600 \mathrm{~cm}^{-1}$, with a maximum of 3401 and $3542 \mathrm{~cm}^{-1}$, that suggests the presence of hydroxyl groups in the sulphated mass. The presence of two intense bands in the IR spectra (bands 1116 and $602 \mathrm{~cm}^{-1}$ ) indicates the presence of the group $\mathrm{SO}_{4}^{2-}$ in this compound [7]. The disappearance of $\mathrm{OH}^{-}$and $\mathrm{SO}_{4}^{2-}$ groups in the residue, after treatment with distilled water, proves a change in the surface properties of minerals that are part of the tailings (Figure 6,c).

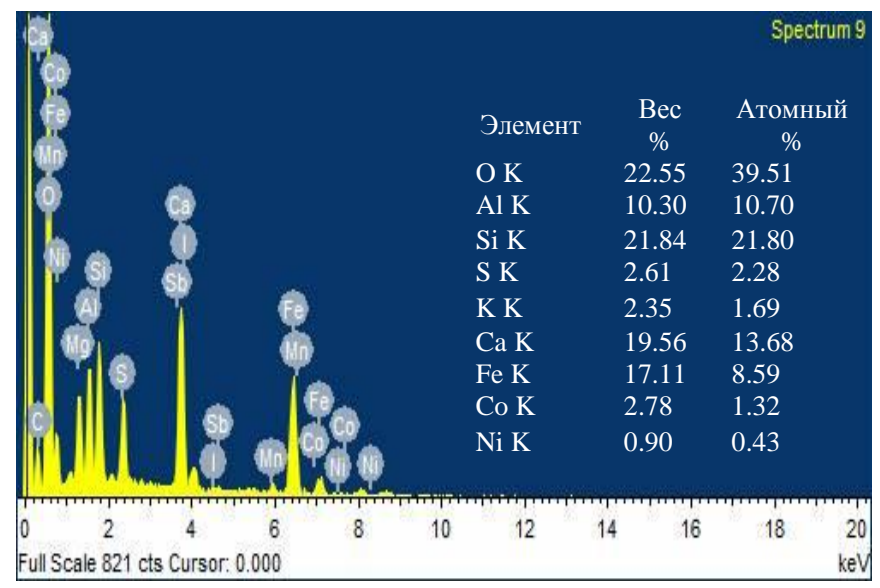

Fig. 5. Results of the EDS analysis of sulphated sample No 1. 

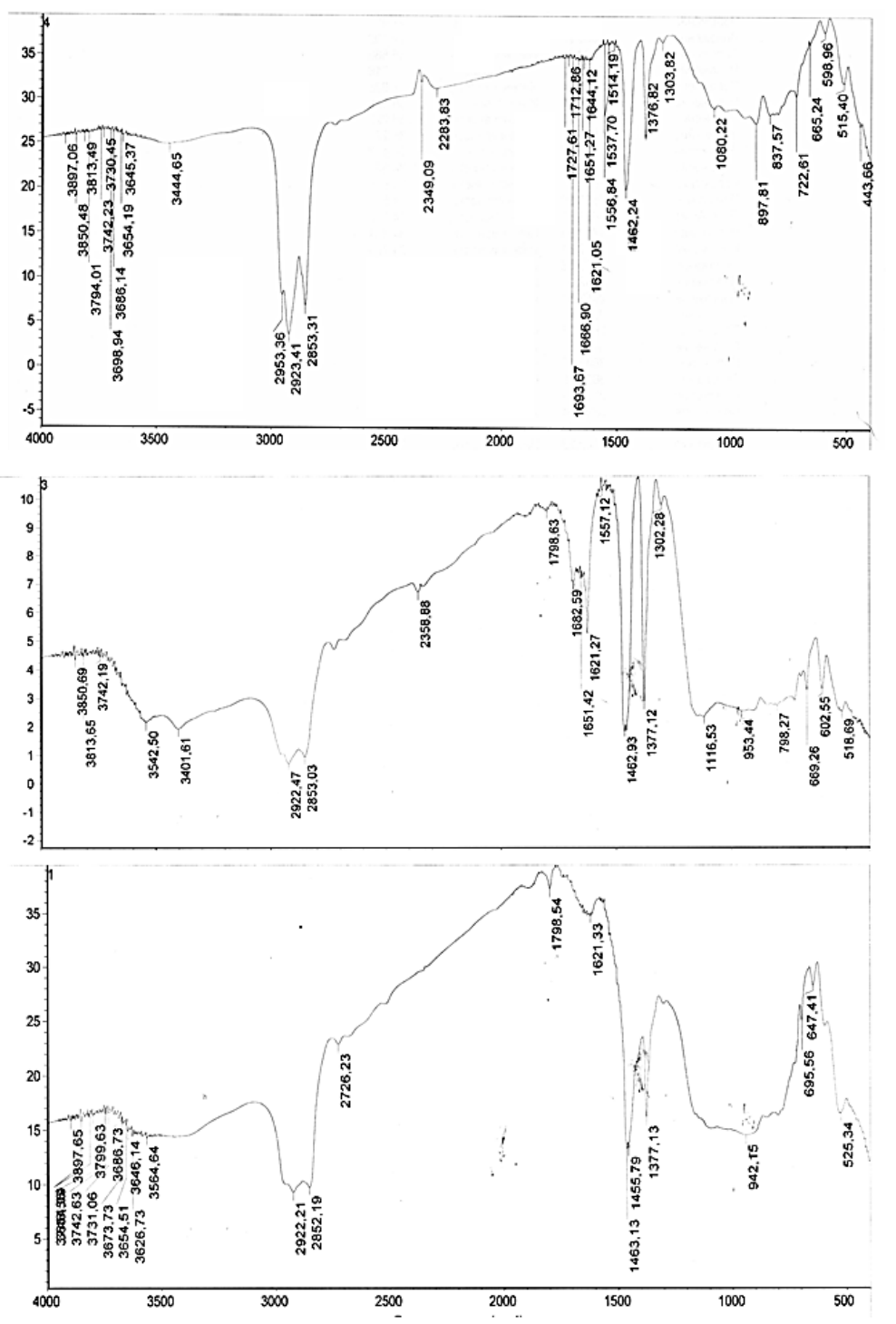

Fig. 6. IR spectra of the initial waste $(a)$, the newly formed peel after drying $(b)$ and the cake after leaching of the sulphated granules with water $(c)$.

\section{Conclusion}

A method for processing tailings has been developed, which ensures a high degree of metal extraction into a productive solution due to the intensification of the heap leaching process. The process includes sulphuric acid agglomeration, which leads to the disclosure of ore splices, the destruction of ore material with the formation of cracks and an increase in permeability, as well as to improved access of leaching solutions. The method allows to obtain selective products of cobalt, copper, zinc and manganese.

\section{References}

1. Meilin Liu, Jiankang Wen, Guikuan Tan, Guoliang Liu, Biao Wu. Experimental studies and pilot plant tests for acid leaching of low-grade copper oxide ores at Tuwu Copper Mine. Hydrometallurgy. 2016. V. 165. P. 227-232.

2. Thriveni Thenepalli, Ramakrishna Chilakala, Lulit Habte, Lai Quang Tuan, and Chun Sik Kim. A Brief Note on the Heap Leaching Technologies for the Recovery of Valuable Metals. Sustainability. 2019. V. 11. P. 3347-3357.

3. Chanturiia V.A., Vigdertauz V.E. Innovatcionnye tekhnologii pererabotki tekhnogennogo mineralnogo syria. Gornyi Zhurnal. 2008. № 6. S. 71-74. 
4. Agatzni-Leonardou S., Tsakikrids P.E., Oustadakis P., Karidakis T., Katsiapi A. Hydrometallurgical process for the separation and recovery of nickel from sulphate heap leach liquor of nickel ferrous Laterite ores. Mineral Engineering. 2009. V. 22. P. 1181-1192.

5. Svetlov A.B, Kravchenko E.A., Selivanova E.A., Seleznev S.G., Makarov D.V., Masloboev V.A. Issledovanie vozmozhnosti kuchnogo vyshchelachivaniia tcvetnykh metallov iz sulfidnogo syria prirodnykh i tekhnogennykh obektov Moorman- skoi oblasti. Ekologiia promyshlennogo proizvodstva. 2015. Vyp. 3. S. 65-72.

6. Alenichev V.M., Umanskii A.B., Cliushnikov A.M. Razrabotka tekhnologii kuchnogo vyshchelachivaniia okislennykh nikelevykh rud Uralskikh mestorozhdenii. Izv. Tomskogo politekhnicheskogo un-ta. 2013. T. 322. № 3. C. 124-128.

7. Nakamato K. Infrakrasnye spektry neorganicheskikh i koordinatcionnykh soedinenii. M.: Mir, $1991.536 \mathrm{c}$.

\title{
DAŞKəSəN DӘMIR FILIZININ EMAL TULLANTILARININ TəRKİBINO DAXIL OLAN MINERALLARIN SəTH XASSəLӘRININ TəDQIQII
}

\begin{abstract}
A.A.Quliyeva
Fiziki-kimyəvi analiz metodları ilə Daşkəsən Filiz saflaşdırma kombinatının dəmir filizi emal tullantılarının tərkibinə daxil olan mineralların oksidləşməsi və səth xassələrinin dəyişməsi tədqiq edilmişdir. Tullantılardan əlvan metalların topa həllolmasının modelləşdirilməsinin laboratoriya tədqiqatlarının nəticələri göstərdi ki, sulphat turşusu ilə aşındırma materialın perkolyasion xassələrini yüksəltməklə əlvan metalların məhlula çıxım faizini artırır.
\end{abstract}

Açar sözlor: zənginlaşmə tullantıları, topa həllolma, sulphatlaşma, metalların çıxarılması.

\section{ИССЛЕДОВАНИЕ ПОВЕРХНОСТНЫХ СВОЙСТВ МИНЕРАЛОВ В СОСТАВЕ ХВОСТОВ ДАШКЕСАНСКИХ ЖЕЛЕЗНЫХ РУД}

\begin{abstract}
А.А.Гулиева
Физико-химическими методами анализа исследовано окисление и изменение поверхностных свойств минералов, входящих в состав хвостов, полученных из железных руд Дашкесанского горно-металлургического комбината. Представлены результаты лабораторных исследований, моделирующих кучное выщелачивание цветных металлов из этих отходов. Показано, что сернокислотная переработка хвостов, полученных из железных руд, улучшает свойства перколяционных материалов и повышает процентное извлечение цветных металлов в раствор.
\end{abstract}

Ключевые слова: хвосты обогащения, кучное выщелачивание, сульфатизащия, извлечение металлов. 